\title{
総説と解説
}

\section{大気光学モデル “FASCODE”一透過率計算と放射輝度}

\author{
竹 内 延 夫 \\ 国立公害研究所 茨城県筑波郡谷田部町小野川 16-2（广305） \\ （1987年 7 月11日受理）
}

Atmospheric Transmittance/Radiance Model "FASCODE"

-Calculation of Transmittance and Radiance

\section{Nobuo TAKEUCHI*}

* National Institute for Environmental Studies, 16-2 Onogawa, Yatabe, Tsukuba, Ibaraki 305, Japan

(Received July 11, 1987)

\section{1. 背景と概 要}

レーザーの発達とともに高感度で精密な分光計測の発 展が著しい：また近年実用化されている人工衛星からの 地球規模の観測では, 衛星センサーは遠隔計測手法を用 いており，そのためには大気の光学的性質の知見は不可 欠となっている. 大気の光学的性質の代表的なものは吸 収, 散乱, 放射過程であり, それらに基づいて一定行路 での透過や放射輝度が計算される。これらの正確な計算 には個々の原子・分子の吸収や散乱のデータに基づいた 膨大な計算を必要とするが, ニンピューターの発達によ って，今まで現実的ではなかった計算が比較的容易にで きるようになった，任意の条件下における大気の透過率 や放射輝度を計算するために AFGL (US Air Force Geophysics Lab.) で開発された大気光学モデル (Atmospheric Transmittance/Radiance Model) は, 一 般に公開されたプログラムとしては現在最も進んだプロ グラムである. AFGLのモデルには，大気を構成する気 体の一本々々の吸収線データからスペクトルの半值半幅 以下の高い精度で計算する FASCODE プログラム132)3) と, その計算結果をデータベースとして分解能を粗くと ったバンドモデルを作り，計算時間を短くした LOW$\mathrm{TRAN}^{4) 5)}$ プログラムがある. 特に LOWTRAN は透 過率や放射輝度の簡便な計算方法として気軽に使用され
ている. ここでは LOWTRAN をFASCODE との関 連から簡単に説明し, その後で FASCODE の計算のア ルゴリズム，使用方法，計算例などを分光計算に使用す る観点から述べる.

\subsection{FASCODE $^{122) 3)}$ と LOWTRAN ${ }^{4) 5)}$}

AFGL で開発された大気光学モデルには高級言語 FORTRAN で最かれた FASCODE と LOWTRAN の 2 種類がある. FASCODE プログラムは HITRAN (HIGH RESOLUTION TRANSMITTANCE) 計画の 一つのプログラム（現在 FASCODE だけが実用的なプ ログラムとして供されている）として製作されたもので， 一本々々の吸収線データを基に, 任意の大気条件下でス ペクトルの半値半幅以下（最小半值半幅の $1 / 4$ まで）の 高分解能で計算するように設計されて和り，0〜 40,000 $\mathrm{cm}^{-1}(0.25 \sim \infty \mu \mathrm{m})$ の波長区間をカバーする.（ただし 吸收線 のパラメータが用意されているのは 0 17,900 $\mathrm{cm}^{-1}(0.56 \sim \infty \mu \mathrm{m})$ の波長区間であり，それより短波 長は LOWTRAN と同じく内藏された吸收帯データを 使用している.) 一方, LOWTRAN (LOW RESOLU. TION TRANSMITTANCE) プログラムは FASCODE の計算結果を基に $5 \mathrm{~cm}^{-1}$ 刻みで収録された吸收係数の データに, ブロードな吸収帯のデータを加兄て，350〜 $40,000 \mathrm{~cm}^{-1}(0.25 \sim 28.5 \mu \mathrm{m})$ の波長区間を $5 \mathrm{~cm}^{-1}$ 刻 みで計算し, 平均化操作によって, $20 \mathrm{~cm}^{-1}$ の分解能で, 
大気の透過率や放射輝度を計算するプログラムである. サブルーチンとして大気中の行路の計算や大気・エアロ ゾルのモデルの選択など多くの組込みデータを用意して いる.これらのサブルーチンは LOWTRAN に導入さ れた後 FASCODE に移植されている. FASCODE は後 の節で詳しく紹介するので，本節では LOWTRAN に ついて FASCODE と関連する部分を紹介する.

LOWTRAN は広範囲のスペクトル領域に亘って分解 能を気にせず，大気の透過率を予測したいといら古くか らの願望を実現したもので，1961年に Altshuler6)によ って提案された手法に従っている. McClatchey et al.7) はこの手法に従って大気の吸収線を一本々々計算し, 各 波長での吸収係数を求め, 一定の波長間隔での吸収強度 をTable とした. 1972年にこれを用いて計算する手法 をコンピューター化して LOWTRAN の第 1 版が 作ら れた．計算のプロセスは以下の $1^{\circ} \sim 3^{\circ}$ の通りである： $1^{\circ}$ : 大気を “ mixed gas” (混合の割合が一定: $\mathrm{CO}_{2}$, $\left.\mathrm{CO}, \mathrm{O}_{2}, \mathrm{CH}_{4}, \mathrm{~N}_{2} \mathrm{O}\right)$ と, 水蒸気とオゾンに分け, それぞ れの気体の $5 \mathrm{~cm}^{-1}$ 刻及（オゾンの可視, 紫外領域は $200 \mathrm{~cm}^{-1}, 500 \mathrm{~cm}^{-1}$ 刻み) の波長での単位濃度当りの吸 収係数を Table として用意する.

計算する大気は地上 $120 \mathrm{~km}$ 迄を考えており, 組込及 データでは地上 $25 \mathrm{~km}$ 迄は $1 \mathrm{~km}$ 毎に, $50 \mathrm{~km}$ 迄は $5 \mathrm{~km}$ 毎に, その後は $70 \mathrm{~km}$ と $100 \mathrm{~km}$ で吸収係数が 与えられている.

$2^{\circ}$ : 選択した大気環境モデル（組込みモデルとして，熱 帯, 中緯度夏 · 冬, 亜寒帯夏 ·冬, 米国標準の 6 つのモ デルが選択できるようになっている）と指定された光路 に従って高度別の各層に分けて柱状分子密度 (column density) を計算する.

$3^{\circ}$ : 吸収係数の 表と柱状分子密度から 透過率を計算す る.

LOWTRAN はいろいろの機能をサブルーチンとして 付加して, 次第に version up された.

【LOWTRAN 2】大気中の光路の計算に地球の曲率 の効果と大気屈折率による屈曲の効果を追加.

【LOWTRAN 3, 3A, 3B】放射輝度の計算, および $\mathrm{HNO}_{3}$ の吸収の寄与を追加.

【LOWTRAN 4】高度依存性, 湿度依存性を持った エアロゾルモデルを導入し，さらに霧（fog）モデルを付 加.

【LOWTRAN 5】4) 以上のモデルを新しいものに更 新.

【LOWTRAN 6】 地球曲率・屈折率の 効果の 計算 法と水蒸気の連続帯のバンドモデルを更新し，太陽や月
からの散乱光の放射の寄与を追加. またより豊富な気象 条件に対応した新しいモデル（風速に依存した海洋エフ ロゾルモデル，鉛直構造エアロゾルモデル，綟雲モデ ル, 雨 (RAIN) モデル)を追加.

現在, 多重散乱の寄与の追加が娭討されている8).

LOWTRAN プログラムは国内でも衛星画像データの 大気効果補正等飞積極的に用いられている99.

\subsection{FASCODE ${ }^{12233)}$ の特徽}

FASCODE (Fast Atmospheric Signature Code) は 一本々々の吸収線データに基づいて, 実験室系だけでな く, 地上 $120 \mathrm{~km}$ 迄の任意の光路の透過率と放射輝度を 計算するプログラムである. FASCODE の特徵を以下 $1^{\circ} \sim 6^{\circ}$ の項目に示す :

$1^{\circ}$. 最も圧力の低いとき（最高高度）のスペクトル幅 $\alpha_{\mathrm{V}}$ (フォイクトプロフォイルを仮定) の 4 分の $1\left(\alpha_{\mathrm{v}} / 4\right)$ の スペクトル精度を有する.

$2^{\circ}$. 任意の環境条件（圧力, 温度)に批ける計算が可能 である.

$3^{\circ}$. 地上 $120 \mathrm{~km}$ 迄の大気空間に対して地球の曲率によ る高度の変化や大気の屈折率による光線の曲がりの補正 を取り入れて光路を正確に計算することが可能である.

$4^{\circ}$. 空間に扑ける吸収と局所平衡定理に基づいた放射輝 度の算出が可能である.

$5^{\circ}$. 大気光学モデル（大気圧力や微量気体濃度の分布） や，エアロゾルモデル等を選択する option が豊富であ る.

$6^{\circ}$. フォイクトプロファイルを解析関数で近似して計算 速度を速めている.

応用面からみた FASCODE の特徵は分子・原子の大 気中のスペクトルを計算機によって合成できることにあ る. 特に高層の大気中の透過率や輝度の測定は実験室で 測定するのは難しいので FASCODE を使用することが 特に有効である. FASCODE の応用としては

(1). 計算機によるスペクトルの合成

任意の大気条件に於けるスペクトルの合成が FASCODEの応用の基本となる. したがって全ての応用がこ の項目に相当するわけであるが，一番典型的な例を挙げ ると, Nipleは $4 \mu \mathrm{m}$ 領域に拉けるスペクトルを計算し， 大気中の測定データから $\mathrm{H}_{2} \mathrm{O}$ や $\mathrm{NO}_{2}$ の濃度を導出す る方法を提案している ${ }^{10)}$.

\section{(2). 徵量気体や吸収の弱、気体の検出}

微量気体や吸収断面積の小さい気体の濃度を吸収法で 導出するには各気体の吸収スペクトルのデータが心要と なる，特に高分解能の測定では単に四収線の中心波長や 断面積のデータだけでなく，各種気体が混在した状態で 
の吸収プロファイルが必要となるので FASCODE が使 用される. Cassidy ら ${ }^{11}$ は中赤外半導体レーザーを光源 として $5 \mathrm{~m}$ の多重光路セルを用いた実験で, $\mathrm{CO}_{2}, \mathrm{CH}_{4}$, $\mathrm{N}_{2} \mathrm{O}$ の濃度を OLP (Optical Line Parameter Compilation: 1982 年版 : 後出)のデータを基に決めている. OLP のデータが計算の基本となるのでその精度が高い ことが必要であるが, Devi ら ${ }^{12)}$ は 7 8 $\mu \mathrm{m}$ 帯の中赤 外半導体レーザーを用いて, $\mathrm{CH}_{4}$ の空気分子との衝突 によるスペクトル線幅を測定して, FASCODE によっ て計算した結果と比較し，良い一致を得ている，紫外領 域では OLPがまだ存在しないので, Trakhovskyは心 ンドモデルに基づいた LOWTRAN を利用してオゾン の長行路濃度測定を行っている ${ }^{13)}$.

(3). 高層大気の計測

前項と関連して，成層圈・中間圈と言った高層では実 験室内でその条件の再現は難しいので, FASCODEによ るスペクトルの合成が特に有効である. Rinsland ${ }^{14) ら は ~}$ バルーン搭載の太陽光を光源とする縁辺法（地球に接す る方向の測定）で $2,400 \mathrm{~cm}^{-1}$ 領域の吸収スペクトルの 測定とFASCODE によって計算したスペクトルとを比 較して $\mathrm{CO}_{2}$ と $\mathrm{N}_{2}$ の吸收を確認している. Rinsland ら ${ }^{15)}$ は同じくバルーン搭載の機器から太陽光を光源とした吸 収スペクトルと FASCODE に基づいて背景光を計算し てそれに酸素分子の $1,400 \sim 1,700 \mathrm{~cm}^{-1}$ の連続吸収帯の データを加えて作成されたスペクトルとを比較して，成 層圈酸素分子濃度の測定を行っている. Coffeyら ${ }^{16)}$ は同 じ様にして航空機から成層圈の HCN のコラム密度を得 ている.

Drummond ${ }^{17)}$ は Nimbus 7 衛星の SAM センサー の測定結果を OLP で計算したスペクトルの上に $\mathrm{H}_{2} \mathrm{O}$ の共鳴螢光を付け加えたスペクトルと比較して高度75〜 $85 \mathrm{~km}$ 領域の $\mathrm{H}_{2} \mathrm{O}$ の混合比は約 $1 \mathrm{ppm}$ であるという 結果を得ている.

\section{(4). レーザー光の大気中での透過率の計算}

大気中のレーザー光の透過率の情報は遠隔計測や飛翔 体のトラッキングにおいて不可欠である. FASCODEで は特に単色光の透過率の計算のためのメニューが用意さ れ，任意の条件下でレーザー光の透過率が容易に計算で きるようになっている. 実際に 3〜5 $\mu \mathrm{m}$ の大気の空領 域における DF レーザー光の $\mathrm{CH}_{4}$ 気体による微少吸収 の実測と FASCODE による計算との比較 ${ }^{18)}$ やう素原 子レーザー波長 $(1.315 \mu \mathrm{m})$ に特ける $\mathrm{H}_{2} \mathrm{O}$ による吸収 の実測と計算の比較 ${ }^{19}$ がなされている.

(5). ライダーによる大気の計測

ライダー(レーザーレーダー)によって大気中の微量
気体の濃度の空間分布を測定するには, 他の気体が共存 する大気中の状態での微量気体のレーザー波長 (2 波長) における吸収俰数が必要である.

この計算に FASCODE が有効な役割を果たす。例え ば, Menyuk ら 20)は波長同調可能な固体レーザー(フォ ノンレーザー) である $\mathrm{Co}: \mathrm{MgF}_{2}$ レーザー (1.5-2.3 $\left.\mu \mathrm{m}\right)$ を光源として， $\mathrm{H}_{2} \mathrm{O}, \mathrm{HCl}, \mathrm{CH}_{4}$ 濃度の空間分布を求める ときに FASCODE を利用している. またGrantら ${ }^{21)}$ $\mathrm{CO}_{2}$ レーザーの 5 組のレーザー線を用いて $\mathrm{H}_{2} \mathrm{O}$ 気体濃 度を求めているが，他のデータとも比較して AFGL の OLP データを基に計算すると約 $30 \%$ の誤差が生じるこ とがあることを報告している.

(6). 区転法による温度, 欧力, 気体濃度の導出

5.1 節, 層別計算のところで触れるよらに, 多チャン ネル (波長もしくは角度) で測定したデータを基に反転 法を利用して温度, 気温, 気体濃度の空間分布を求める ことが可能である. 例えば Hoellらら ${ }^{22)}$ は地上から ${ }^{13} \mathrm{C}^{16} \mathrm{O}_{2}$ レーザーを局部発振光とするへテロダイン分光計を用い て大気中のフンモニアの空間分布の測定を行っている. この際に反転法に使用する荷重関数の導出にFASCODE を使用している.

\section{(7). ジンドモデルパラメーターの決定}

大気の光学モデルではスペクトルの変化は緩やかで波 長の刻みは粗くて良いことが多い. OLP を基にバンド モデルのパラメーターの計算のアルゴリズムが提案さ れ，微量気体について計算された ${ }^{23)}$. またこの結果は分 解能 $5 \mathrm{~cm}^{-1}$ の LOWTRAN5 の作成のときに使用され ている24).

(8). 大気の光学モデル

さらにWehrbein ら ${ }^{26)} は \mathrm{CO}_{2}, \mathrm{O}_{3}$ の吸収, 放射を取 り入れて, 中層大気 (成層圈, 中間圈) の加熱, 冷却の 計算に OLP P FASCODE を使用している. また, 地 球誕生以来の地表温度の变化の経緯を $\mathrm{CO}_{2} \ngtr \mathrm{CH}_{4}$ の放 射の性質を取り入れた議論に AFGL のプログラムが使 用されている26).

(9). 分子分光の研究

分子分光データを解析するときは不必要な干渉気体の スペクトルが邪魔になることが往々にして生じる．この 様なときに FASCODE を用いると非常に便利である ${ }^{27) . ~}$ (10). 放射輝度の計算

FASCODE は放射輝度 (分光放射強度)の計算子可能 である. 周波数 (波長) の関数として大㔕からの放射輝 度を測定し, 反転法により温度の空間分布を求めるとさ の荷重関数を求めることができる.

本解説では分光計測的観点から任意の条件下に打る 
吸収と透過の計算への 利用に焦点を置いて FASCODE の構造,アルゴリズム，表示法を含めた使用法を紹介す る. 使用法の紹介に当たっては, 使用の際に便利なよう に，豊富な option の中から希望するケースを選択する 方法，あるいは任意のケースを設定する方法を紹介する.

大気の放射輝度計算については, 簡単に触れるにとど め, その詳しい紹介は別の機会に譲る.

また，本プログラムを周波教変調法などの計算に払張 する場合について簡単に触れる。

\section{FASCODE プログラム}

FASCODEは気体の吸収線を一本々々計算する高分解 能な大気光学モデルの内で唯一の実用的なプログラムで ある. FASCODEでは計算時間を短縮するために分子の 運動速度で決まるドップラー拡がり (Gauss 型) と分子 の衝突によって決まる衝突拡がり (Lorentz 型) との convolution で与兄られる Voigt 払がりをGauss 関 数と Lorentz 関数の 2 種類 (FASCOD2 では Voigt Error Function を加えた 3 種）の解析関数の和で近似 している28,29,30)．1985年10月に version up された FASCOD2 ${ }^{3)}$ では計算方法に工夫を加えて, 常時 Voigt profile の計算方式を使用しても Lorentz 型や Doppler 型の場合と違わないまでに速度を向上させている，さら に LOWTRAN 5 に付属された多くの組込及機能を受 け継いで拈り, OLP (Optical Line Parameter Compilation：1982年版）の吸収線データは $17,900 \mathrm{~cm}^{-1}$ 迄 であるが，連続帯については $\mathrm{N}_{2}\left(2,020-2,800 \mathrm{~cm}^{-1}\right)$ と $\mathrm{O}_{2}\left(1,395-1,760 \mathrm{~cm}^{-1}\right), \mathrm{H}_{2} \mathrm{O}\left(0-20,000 \mathrm{~cm}^{-1}\right)$ のバン ト., $\mathrm{O}_{3}$ (Chappuis $13,000-23,600 \mathrm{~cm}^{-1}$; Hartley-Huggins $\left.27,370-40,800 \mathrm{~cm}^{-1}\right)$ の拡散帯を取り入れている. 従って， のの波長から紫外領域の $250 \mathrm{~nm}$ まで計算する ことができる. 以下 FASCODE プログラムの紹介に当 たっては FASCOD2 を中心に考える。

\section{1 アルゴリズムと計算速度向上の原理}

FASCODEでは均一な光路の波数に括ける光学的厚さ $k(\nu)$ を計算するのに Van Vleck and Huber ${ }^{311}$ によっ て与えられる各遷移からの寄与の和として次のように示 す：

$$
\begin{aligned}
& k(\nu)=\nu \tanh (\beta \nu / 2) \sum_{i} W\left(m_{i}\right) \tilde{S}_{i}(T)[f(\nu)+f(-\nu)] \\
& \text { ここで }
\end{aligned}
$$

$$
\beta=h c / k T
$$

$W\left(m_{i}\right): i$ 番目の遷移（波数 $\nu_{i}$ ) 飞対応する分子 $m_{i}$ のコラム密度 (分子 $\left./ \mathrm{cm}^{2}\right)$

$\tilde{S}_{i}(T)$ : 温度 $T\left({ }^{\circ} \mathrm{K}\right)$ に扣ける遷移強度 $\left(\mathrm{cm}^{2} /\right.$ 分子 $)$ $f(\nu)$ : 線形 (line profile) 関数 $\left(1 / \mathrm{cm}^{-1}\right)$ である. $\tilde{S}_{i}(T)$ は

$$
\begin{aligned}
& \tilde{S}_{i}(T)=\left(8 \pi^{3} \times 10^{-36} / 3 h c\right) \cdot \mu_{i}{ }^{2}\left(1+e^{-\hat{\beta} v_{i}}\right) e^{-\beta E_{i}} / \\
& Q_{v}(T) Q_{R}(T)
\end{aligned}
$$

で与兄られる. $\mu_{i}{ }^{2}$ は遷移強度 $\left(\right.$ debye $\left.^{2}\right), E_{i}$ は遷移の下 位準位エネルギー $\left(\mathrm{cm}^{-1}\right)$ である. $Q_{v}(T)$ と $Q_{R}(T)$ は対 応する分子種の振動および回転の分配関数である.この 遷移強度 $S_{i}(T)$ の定義は AFGL の吸収線データ ${ }^{32,33,34)}$ (OLP: AFGL optical line parameter compilation) で 用いられている $S_{i}(T)\left(\left(\mathrm{cm}^{2} /\right.\right.$ 分子 $\left.) \cdot \mathrm{cm}^{-1}\right)$ とは

$$
\tilde{S}_{i}(T)=S_{i}(T) /\left(\nu_{i} \tanh \left(\beta \nu_{i} / 2\right)\right)
$$

の関係がある. OLP では $T=296^{\circ} \mathrm{K}, 1$ 気圧のデータが 収録されている。

吸収線の形 $f(\nu)$ は衛突幅で決まるときには

$$
f_{L}(\nu)=\frac{1}{\pi} \cdot \frac{\alpha_{i}}{\left(\nu-\nu_{i}\right)^{2}+\alpha_{i}{ }^{2}} \chi\left(\left|\nu-\nu_{i}\right|\right)
$$

で与えられる. $\chi\left(\left|\nu-\nu_{i}\right|\right)$ は Lorentz 関数からのずれを 示し, $\mathrm{H}_{2} \mathrm{O}$ では連続帯として取り入れられて和り， $\mathrm{CO}_{2}{ }^{17)}$ では直接与えられている. 衝突幅 (半幅) は

$$
\alpha_{i}(T)=\alpha\left(T_{0}\right)\left(\rho / \rho_{0}\right)\left(T / T_{0}\right)^{x}
$$

で与えられる， $\rho$ は密度であり,$x$ は分子に固有の定数 である.

以上のように line-by-line の計算は (1) 式を逐次行う ことによって各波長での光学的厚さが計算される.

FASCODEでは計算速度を高めるために種々の工夫を 行っている. 1) Voigt profile は積分形をして拉り，解析 関数でないのでその計算には時間が掛かる. FASCODE では Voigt profileを解析関数で近似し，計算時間を短 縮している．2）補間法を十分に活用し，吸収線 profile の裾のように変化がゆっくりしているところでは，計算 点を粗くとって, 補間によって中間の点の值を求めて計 算時間の効率化を図っている.

Voigt-profile は convolution の形で

$$
\begin{aligned}
& f_{\mathrm{v}}(\nu)=\frac{1}{\alpha_{D}} \cdot \frac{p}{\pi} \int_{-\infty}^{\infty} \frac{\exp \left(-y^{2}\right)}{p^{2}+(d-y)^{2}} \mathrm{~d} y \\
& d=\left(\nu-\nu_{0}\right) \sqrt{\ln 2} / \alpha_{D} ; \quad p=\alpha_{L} \sqrt{\ln 2} / \alpha_{D}
\end{aligned}
$$

と表せる.ここで $\alpha_{D}$ は Doppler limit の幅, $\alpha_{L}$ は (5) 式で与兄られる衝突幅で温度・圧力の関数である.

(6) 式では $\alpha_{L}$ と $\alpha_{D}$ の 2 つの半值半幅を用いているが, FASCODE では Voigt profile の半値半幅 $\alpha_{\mathrm{v}}, 1$ つだけ を用いる。 $\alpha_{\mathrm{v}}$ は 
$\alpha_{\mathrm{v}}=\alpha_{L}(1+\varepsilon) / 2+\left\{\alpha_{L}^{2}(1-\varepsilon)^{2} / 4+\alpha_{D}^{2}\right\}^{1 / 2}$ $\varepsilon=0.0990 \ln 2$

と近似される12)。このときに Voigt parameter $\zeta$

$$
\zeta=\alpha_{L} /\left(\alpha_{L}+\alpha_{D}\right)
$$

を用いて $\alpha_{\mathrm{v}}$ を議論するのが便利である. $0<\zeta<0.5$ の とき $\alpha_{\mathrm{v}}$ は $\alpha_{D}$ に近く, $0.5<\zeta<1.0$ のとき $\alpha_{\nabla}$ は $\alpha_{L}$ K 近い. 初版の FASCODE ではこの $\alpha_{\mathrm{v}}$ を半值幅として Voigt profile ((6) 式) は Doppler profile と Lorentz profile との和で

$$
f_{\mathrm{v}}\left(\zeta, \alpha_{\mathrm{v}}, \nu\right)=(1-C(\zeta)) f_{D}\left(\alpha_{v}, \nu\right)+C(\zeta) f_{L}\left(\alpha_{\nabla}, \nu\right)
$$

と表わした：この近似を取り入れたサブルーチンを HIRAC 1 と呼ぶ. $f_{n}$ は Doppler profile で

$$
\left.f_{D}\left(\alpha_{\mathrm{v}}, \nu\right)=\sqrt{\ln 2 / \pi}\right) / \alpha_{\nabla} \cdot \exp \left\{-\ln 2 \cdot\left(\nu-\nu_{0}\right)^{2} / \alpha_{\mathrm{v}}{ }^{2}\right\}
$$

である.ささらに $f_{D}$ は非常に早く收束するが, $f_{L}$ は裙を 引くので, $f_{L}$ を収束の速さによって $f_{1}, f_{2}, f_{3}, f_{4}, f_{5}$ の 5 つの関数（初版の FASCODE では $f_{1}, f_{2}, f_{3}$ まで）に 分け, 計算の波数領域の刻みを变えて計算の効率化を図 っている. すなわち, $\boldsymbol{z}=\left(\nu-\nu_{0}\right) / \alpha_{\mathrm{v}}$ (関数 $f_{L}, f_{D}$ は原点 に関し対称なので $z>0$ のみを考える）とするとき， $f_{1}$
は $0 \leqq z \leqq 4$ 以外では 0 となる関数で $\Delta z=1 / 4$ (すなわち $\left.\alpha_{\mathrm{v}} / 4\right)$ の刻及で計算される.（ $f_{D}$ は $0 \leqq z \leqq 4$ の外では 10-7 以下となるので無視される.） $f_{2}$ は $0 \leqq z<16$ 以外で は 0 となる関数で $\Delta z=1$ の刻みで計算される. 同様に $f_{3}$ は $0 \leqq z<64$ の区間を $\Delta z=4$ の刻みで， $f_{4}$ は $64 \leqq$ $z \leqq 256$ の区間を $\Delta z=16$ の刻みで計算される， $f_{5}$ は $Z=256$ に打ける $f_{L}$ の值で残差を補正する. $f_{1}, f_{2}, f_{3}$ で 全体の $97 \%$ をカバーする.（したがって，計算時間を短 縮するときは $f_{4}$ を省略することができる.）関数 $f_{D}, f_{1}$, $f_{2}, f_{3}$ の振舞いを Fig. 1 亿示す.

関数 $f_{D}, f_{1}, f_{2}, f_{3}, f_{4}, f_{5}$ から $f_{\mathrm{v}}$ を合成するには各関 数 $f_{i}$ の計算の刻及が異なるので， $f_{4}$ を $f_{3}$ に加え，そ の合計の $f_{3}$ を $f_{2}$ に，そのまた合計の $f_{2}$ を $f_{1}$ に加光 る. その際に次第に細かい刻みとなるので，細かい刻み に揃えるために補間法を用いる，初版の FASCODE で は (9) 式の係数 $C(\zeta)$ は Voigt parameter $\zeta$ の関数て 各 $\zeta$ の值 (0.01 刻み) 毎に profile 上の点でずれがむ っとも小さくなるように最小自乗法で求め, 予め表とし て与えた. FASCOD1B 以下 (したがって FASCOD2 も) ではさらに精度を上げるために, $f_{1}, f_{2}, f_{3}, f_{4}$ の係数を 独立に取っている.これらの関数の形は Table 1 で示
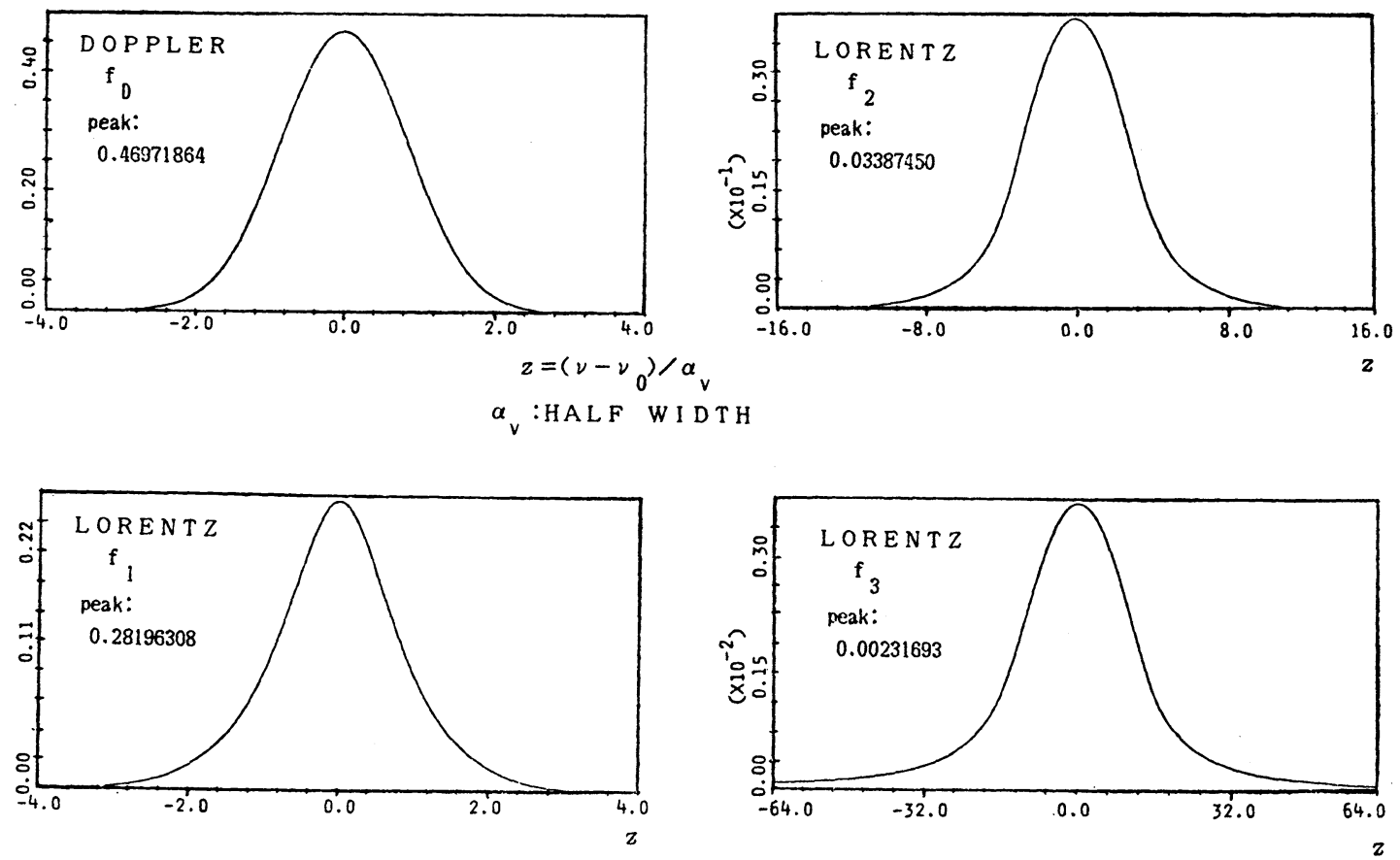

Fig. 1 Function for the reconstruction of the Voight line shape function. Doppler; $f_{D}$ (peak: 0.46971864), Lorentz subfunctions; $f_{1}$ (peak: 0.28196308), $f_{2}$ (peak: 0.0337450), $f_{3}$ (peak: 0.00231693), $f_{4}$ (peak: $0.00014565,-256<z<256$ ) and error function $V_{e}$ (peak: $0.48280359,-4<z<4$ ) are not shown. 
Table 1. Functions for the reconstruction of the Voigt line shape function.

\begin{tabular}{|c|c|c|c|c|c|}
\hline \multirow{2}{*}{ Function } & \multicolumn{4}{|c|}{ Domain } & \multirow{2}{*}{$\int_{-\infty}^{\infty} f(z) \mathrm{d} z$} \\
\hline & $0 \leqq z \leqq 4$ & $4 \leqq z<16$ & $16 \leqq z<64$ & $64 \leqq z \leqq 256$ & \\
\hline \multicolumn{6}{|c|}{ (Doppler) } \\
\hline$f_{D}(z)$ & $f_{D}(z)$ & 0 & 0 & 0 & 1.000 \\
\hline \multicolumn{6}{|c|}{ (Lorentz) } \\
\hline$f_{1}(z)$ & $L(z)-Q_{1}(z)$ & 0 & 0 & 0 & 0.600 \\
\hline$f_{2}(z)$ & $Q_{1}(z)-Q_{2}(z)$ & $L(z)-Q_{2}(z)$ & 0 & 0 & 0.294 \\
\hline$f_{3}(z)$ & $Q_{2}(z)-Q_{3}(z)$ & $Q_{2}(z)-Q_{3}(z)$ & $L(z)-Q_{3}(z)$ & 0 & 0.079 \\
\hline$f_{4}(z)$ & $Q_{3}(z)-L(256)$ & $Q_{3}(z)-L(256)$ & $Q_{3}(z)-L(256)$ & $L(z)-L(256)$ & 0.021 \\
\hline$f_{5}(z)$ & $L(256)$ & $L(256)$ & $L(256)$ & $L(256)$ & 0.005 \\
\hline \multicolumn{6}{|c|}{ (Voigt Error) } \\
\hline$V e(z)$ & $V e(z)$ & 0 & 0 & 0 & 1.000 \\
\hline
\end{tabular}

されているが，それぞれの境界 $z_{i}$ で関数およびその微 分値が0となる様にとってある. Table 1 の関数 $f_{i}(z)$ は (9) 式の $f_{L}\left(\alpha_{\mathrm{v}}, \nu\right)$ を分解し, 変数を ע から $z$ にし たものである. $f(z) \mathrm{d} z=f(\nu) \mathrm{d} \nu$ の関係に注意する必要が ある2). Table 1 で

$$
\begin{aligned}
& L(z)=1 /\left(1+z^{2}\right), \\
& Q_{i}(z)=\left(1+2 z_{i}{ }^{2}-z^{2}\right) /\left(1+z_{i}{ }^{2}\right)^{2}, \\
& z_{i}=4^{i}, \\
& V e(z)=\sqrt{\left(b_{0} / \pi\right)} \exp \left(-b_{0} z^{2}\right) \\
& \quad \cdot\left(b_{1}+2 b_{2} b_{0} z^{2}+4 b_{3} b_{0}{ }^{2} z^{4}\right) /\left(b_{1}+b_{2}+b_{3}\right)
\end{aligned}
$$

である. $V e(z)$ は Voigt error と呼ばれ, $f_{5}$ にって

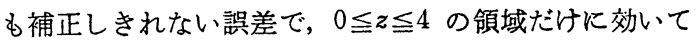
くる.

Table 1 の関数を用いて,

$$
\begin{aligned}
f_{\mathrm{v}}(\zeta, & \left.\alpha_{\mathrm{v}}, \nu\right) / \alpha_{\mathrm{v}} \\
= & C_{D}(\zeta) \cdot f_{D}(z)+C_{1}(\zeta) \cdot f_{1}(z)+C_{2}(\zeta) \cdot f_{2}(z) \\
& +C_{3}(z) \cdot f_{3}(z)+\left(\alpha_{c} / \alpha_{\mathrm{v}}\right)\left[f_{4}(z)+f_{5}(z)\right] \\
& +C_{\mathrm{v} e}(\zeta) \cdot V e(z)
\end{aligned}
$$

と表わされる. 係数 $C_{i}$ は各 $\zeta$ 毎に計算する点 $z$ での ずれが最小になるように最小自乗法（重回帰分析）によ って求められ，表として与えられている．また関数形は subroutine HIRAC1 の中の subroutine SHAPEL に よって計算され, 予め配列としてしまわれ, 各 $z$ の值に 対して，配列から数値を読みだして計算速度を速めてい る. 以上の工夫によって, 全ての圧力で Voigt profile を用いて光学的厚さを計算することができる.

\subsection{Optical Line Parameter}

FASCODE で（1）式を用いて line-by-line 計算を行 うには，気体分子一本々ヶのデータが必要である．この データベースとなるのが Optical Line Parameter Compilation（“吸収線データ”）である.これには波数 $0 \sim 17,900 \mathrm{~cm}^{-1}$ (波長 $0.56 \sim \infty \mu \mathrm{m}$ ) の範囲の主成分気 体 ${ }^{33}$ ) と波数 $0 \sim 10,000 \mathrm{~cm}^{-1}$ (波長 $1.0 \sim \infty \mu \mathrm{m}$ ) の範囲 の微量成分気体の ${ }^{34)}$ の 2 種類がある. 吸収線データは数 年毎に改訂されているが, 1982 年版では波数 0-17,900 $\mathrm{cm}^{-1}$ の大気の主成分気体 ( 7 種: $\mathrm{H}_{2} \mathrm{O}, \mathrm{CO}_{2}, \mathrm{CO}, \mathrm{O}_{2}$, $\left.\mathrm{N}_{2} \mathrm{O}, \mathrm{CH}_{4}, \mathrm{O}_{3}\right)$ の吸収線は 180,956 本が, 波数 0-10,000

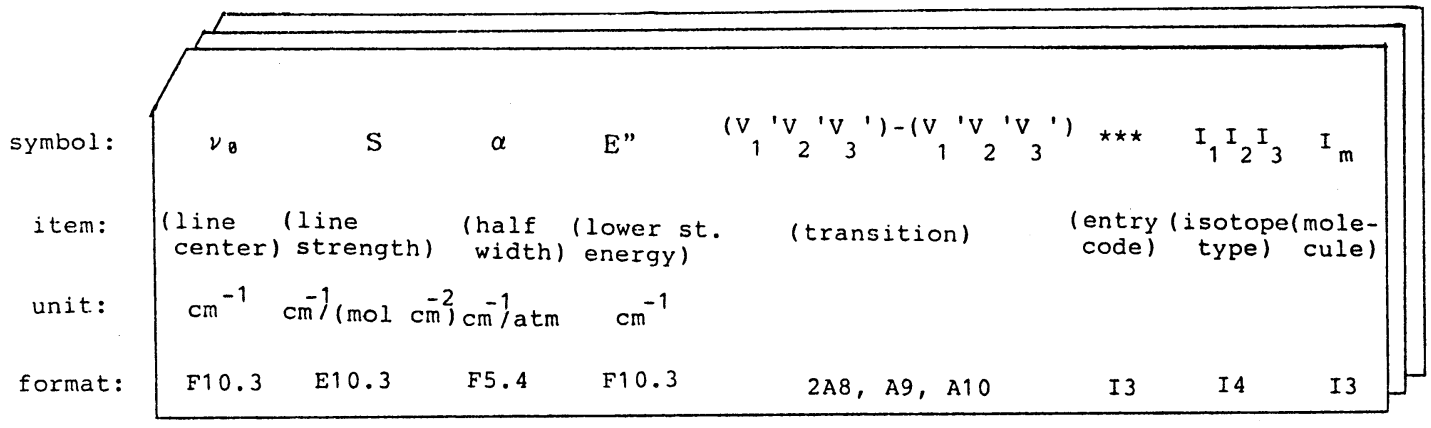

Fig. 2 Format of AFGL optical line pasameter compilation ( 80 columus). 
Table 2 Numbers of species and lines cited in AFGL OLP compilation.

\begin{tabular}{llrrlrllr}
\hline \multicolumn{1}{c}{$\begin{array}{c}\text { Major Component } \\
(180,956 \text { lines })\end{array}$} & \multicolumn{6}{c}{ Minor Component } \\
\hline 1 & $\mathrm{H}_{2} \mathrm{O}$ & 48,876 & 8 & $\mathrm{NO}$ & 7,375 & 19 & $\mathrm{OCS}$ & 737 \\
2 & $\mathrm{CO}_{2}$ & 56,510 & 9 & $\mathrm{SO}_{2}$ & 18,169 & 20 & $\mathrm{H}_{2} \mathrm{CO}$ & 2,701 \\
3 & $\mathrm{O}_{3}$ & 43,977 & 10 & $\mathrm{NO}_{2}$ & 9,456 & 21 & $\mathrm{HOCl}$ & 7,723 \\
4 & $\mathrm{~N}_{2} \mathrm{O}$ & 15,844 & 11 & $\mathrm{NH}_{3}$ & 5,556 & 22 & $\mathrm{~N}_{2}$ & 117 \\
5 & $\mathrm{CO}$ & 574 & 12 & $\mathrm{HNO}_{3}$ & 12,777 & 23 & $\mathrm{HCN}$ & 772 \\
6 & $\mathrm{CH}_{4}$ & 13,005 & 13 & $\mathrm{OH}$ & 8,490 & 24 & $\mathrm{CH}_{3} \mathrm{Cl}$ & 6,687 \\
7 & $\mathrm{O}_{2}$ & 2,164 & 14 & $\mathrm{HF}$ & 62 & 25 & $\mathrm{H}_{2} \mathrm{O}_{2}$ & 2,389 \\
& & & 15 & $\mathrm{HCl}$ & 200 & 26 & $\mathrm{C}_{2} \mathrm{H}_{2}$ & 306 \\
& & 16 & $\mathrm{HBr}$ & 256 & 27 & $\mathrm{C}_{2} \mathrm{H}_{6}$ & 4,328 \\
& & 17 & $\mathrm{HI}$ & 145 & 28 & $\mathrm{PH}_{3}$ & 2,886 \\
& & 18 & $\mathrm{ClO}$ & 6,020 & & & \\
\hline
\end{tabular}

$\mathrm{cm}^{-1}$ の微量成分気体 21 種の吸収線は 97,162 本が収録さ れている. (FASCODE プログラム自体は主成分気体, 微量成分気体併せて 64 種類まで㧪張できる構造になって (る)。吸收線データは 1 本の吸収線が FORTRAN カ ード1枚のイメージで作成されており，80 column に Fig. 2 の format で記録されている. 項目は遷移の中 心波数 $\nu_{0}\left(\mathrm{~cm}^{-1}\right)$, 要移強度 $S\left(\mathrm{~cm}^{-1} /\left(\right.\right.$ 分子 $\left.\left.\cdot \mathrm{cm}^{-2}\right)\right)$, 半 値半幅 $\alpha\left(\mathrm{cm}^{-1}\right.$ 気压), 下位準位エネルギー $E^{\prime \prime}\left(\mathrm{cm}^{-1}\right)$, 遷移の同定，出典を区別する記号，同位体の区別，分子 の種類が採録されている，収録されている主成分気体の 遷移は最も長い光路（地上 $120 \mathrm{~km}$ の点から地表面に接 して再び地上 $120 \mathrm{~km}$ の点に達する光路）を取ったとき 大気の吸収が10\%以上となる吸収線が選択されている.

（微量成分気体ではこの基準は明確でない）僄移強度 $S$ は(3)式に述べた定義に従って括り, 半值半幅 $\alpha$ と共に 1 気压, $296 \mathrm{~K}\left(23^{\circ} \mathrm{C}\right)$ の值である. OLP に収録された 分子の番号と収録本数を Table 2 に示す，収録された 遷移については文献 33)，34）を参照されたい，最近OLP の 1986 年版が入手できるようになった ${ }^{36)}$. 詳しくは Applied Optics の10月 1 日号(1987年)を参照して頂く ことにして，簡単に概要を紹介すると各遷移線の情報は 100 character で書かれている (1982 年版では 80 character)。これには遷移磪率 (Debye 単位: 部分的に空白), self-broadening のスペクトル線幅, 品気分子との衝突 によるスペクトル拡がりの温度依存性 ((5)式の $x)$, 遷 移周波数の圧カシフト, 周波数, 強度, 半値幅別の䛇差 と出典のデータも加えられている. OLP の 1986 年版で は主成分気体, 微量気体両者のデータは 1 つのファイル に統合され, さらに約 7 万本のデータが追加され, 全体 で 348, 043 本となっている.

また OLPに関連したデータとして France から出て
いる GEISHA ${ }^{37)}$ があり, FASCODE と同じ format (80 character) で書かれている.

な扮連続帯については衝突励起の $\mathrm{N}_{2}(2,020-2,800$ $\left.\mathrm{cm}^{-1}\right)$ と $\mathrm{O}_{2}\left(1,395-1,760 \mathrm{~cm}^{-1}\right)$ のバンドと $\mathrm{H}_{2} \mathrm{O}(0-$ $\left.20,000 \mathrm{~cm}^{-1}\right)$ の自己括よび異種衝突拡がりによる裾の拻 がり, $\mathrm{O}_{3}$ (Chappuis $13,000-23,600 \mathrm{~cm}^{-1}$; HartleyHuggins 27,370-40,800 $\left.\mathrm{cm}^{-1}\right)$ の払散帯を取り入れてい る.

\section{3 プログラムの構成}

FASCOD2 は約23, 000行の FORTRAN で書かれたプ ログラムで, 151のサブルーチン(その他に計40の block data と文関数) から成る. 計算機のディスク上に記憶す るときには約 1,100 kByte のメモリーを必要とする.

FASCOD 2 のプログラム tree は Fig. 3 のような構成を している. 固定波長の計算をするときには subroutine LASER が用いられるが，ある波長区間のスペクトルの 計算を行らときには subroutine XLAYER を使用する. 【XLAYER】指定されたパラメーターに従って, 光路

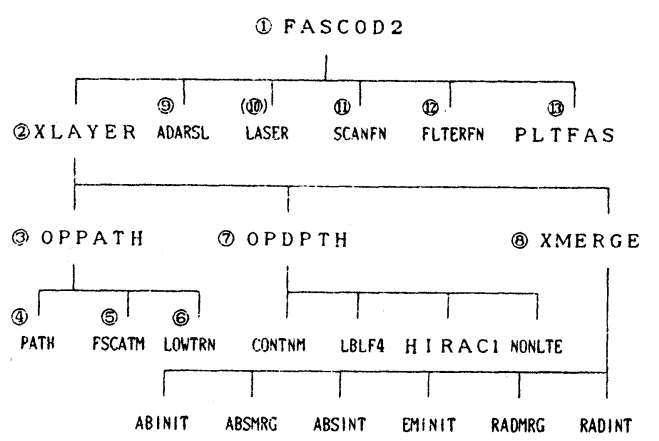

Fig. 3 Program structure of FASCOD2. The sequence of the calculation is shown by the number in a circle. 
を層状に分け，更に下位の subroutine で光路, 光学的 厚さを計算する。

【OPPATH】さらに下位の subroutine FSCATM で 選択された（あるいは user が与えた）大気モデルの気 圧, 温度, 空気分子成分比を用いて大気中の任意の 2 点 間の行路を地上高度別の層に分類し，その層に含まれる 柱状分子数密度を種類毎に計算する. エアロゾルを選択 するとき, subroutine LOWTRN で選択したエアロゾ ルモデルを基に波数毎の散乱, 吸収強度のファイルを製 作する.

【OPDPTH】 OPPATH で求められた層別の分子数密度 （柱状分子密度）を用いて下層から optical depth を計 算する. さらにこの subroutine の下位にあるCONTNM で連続帯の効果が取り入れられ，NONLTE で非平衡状 態の放射輝度の効果が計算される。

【XMERGE】透過率か光学的厚さか, 放射輝度の計算 かによって必要な量に変換し, 層別の量を加え合わせ て, 光路全体の量を計算する.

【ADARSL】 subroutine LOWTRN の中で製作した アイルを基にェアロゾルの吸収や散乱の寄与を各波長で の光学的厚さに加えるプログラムである.

【LASER】一個または複数個の波長での透過率を計算 するルーチンでレーザー光の透過率を計算するのに適し ている.

【SCANFN】分光器のスリット関数で透過光の加重平 均をとる.

【FLTRFN】狭帯域の光学フィルターや分光器のスリ ットを通したときの透過率である.

【PLTFAS】プロッターK作戝するルーチンである.

\section{3. 使 用 法}

本節では実際に FASCOD2 を使用する手順を紹介す る.これにはFig. 4 に示すよらに OLP データから入 カフォイル FILE 3 を作ってから, 計算条件を SYSIN. DATA として指定して, 全光路に亘る光学的厚さある いは透過率，放射輝度を FILE 10１2 に作成し，それ をPLTFASによって圀示するるのである. 以下，計算 の手順に従って使用法を説明する.

\section{1 入カファイルの準備}

OLP (Optical Line Parameter) 飞收録されている吸 収線データのらち, 透過率のプロファイルの計算に必要 なデータは遷移の中心波長 $\nu_{0}$, 遷移の強度 $S$, 半値半幅 $\alpha$ ，遷移の下位準位のエネルギー $E^{\prime \prime}$ と分子の種類であ る. FASCODEでは遷移波数の低い方から高い方へ順次 並べられたデータから指定した範囲内の選択された分子

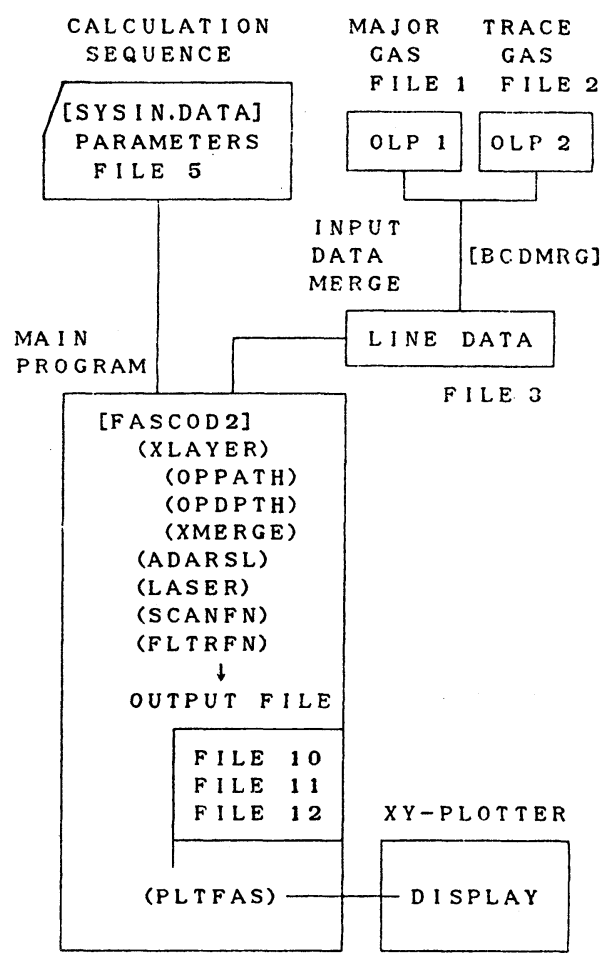

Fig. 4 Process of calculation of the optical thickness and radiance by FASCOD2.

種の全ての吸収線を計算する. OLP は主成分気体 (Major component: Fig. 4 での OLPMJ.DATA) ば かりでなく, 微量気体 (trace gas: OLPTR.DATA) p user が提供する吸収線データも加える必要がでてくる. FASCOD 2 には BCDMRG が用意されて怙り, 主成分 気体の OLPMJ.DATA や微量成分の OLPTR.DATA やその他 user が用意したデータフォイルから FASCODE に直接入力できる FILE 3 を作成する.プ ログラム BCDMRG は1つもしくは2つのファイルか ら計算に取り入れる吸収線を波数順に並べる機能の他 に，非局所平衡定理に基づいて放射輝度を計算するとき に必要な遷移の上準位や下準位の振動準位の指標を書き 込む機能も有する.

\section{2 パラメーターの設定}

透過率・放射輝度の計算に関与する分子は入力ファイ ル (IFILE 3) 製作の際に選定されるが，その他の環境条 件 (温度, 湿度, 実験室内 ·大気環境の区別：高度, 大 気条件, エアロゾル 条件, 雲・霧・雨など）や光路は SYSIN.DATA として FORTRAN のカードのイメー ジで入力するようになっている，入力項目を見るとどの 様な条件が設定できるかも分かるので，カードの順に從 
って紹介する.

[CARD 1.1] 計算の識別用のメモ (80文字).

[CARD 1.2] このカードはどの様な計算を行うかを選 択するスウィッチの役割を果している．以下の項目を選 択するようになっている.

IHIRAC: 計算方式 (LINE-BY-LINE, NLTE, 中心 の寄与の除外など),

ICNTNM：連続帯の選択,

IAERSL : エアロゾル (LOWTRAN モデル) の選択,

IEMIT : 光学的厚さのみか放射輝度も含むか,

ISCAN : 装置関数との convolution,

IFILTR：フィルター透過量の計算,

IPLT : プロッターへの表示,

ITEST：1を選択すると FASCODE に内蔵されたデ 一タ（波数領域：0-50 $\mathrm{cm}^{-1}$ ) を入力データ (FILE 3) と

して用いてプログラムが正しいかどうかチェックする.

IATM : 大気モデル,

IMRG : 層別計算の加方方, IMRG の値の指定によっ て FILE 10 に各層の光学的厚さ, 全積算量, 最後の層 の光学的厚さのいずれかが記録される.

ILAS：レーザー波長の計算, などの選択

[CARD 1.3] 計算範囲 $\left(\mathrm{cm}^{-1}\right.$ : 一回の計算範囲は最大 $\left.525 \mathrm{~cm}^{-1}\right)$, 刻み $\left(\mathrm{cm}^{-1}\right)$.

[CARD 1.4] 境界（地表面）の温度之放射率.

[CARD 1.5] 大気モデルが選択されなかったとき $(\mathrm{IATM}=0)$, 大気の層の数, 構成分子数, 平均温度 - 圧 力, 光路, 層別分子の密度など大気構造を user が与え る.

[CARD 2.1] 大気モデルが選択されたとき $(\mathrm{IATM}=1)$, 大気モデルの選択, 光路の種別 (ITYPE), 層の作成法, などを与える.

[CARD 2.2-2.4] ITYPE $=1:$ 水平光路

2: $\mathrm{H} 1$ から $\mathrm{H} 2$ への 斜め光路

$3: \mathrm{H} 1$ から宇宙への斜め光路,

に応じて, 両端高度, 距離, 角度, 地球へ接するかどう かを規定する.

[CARD 2.5-2.6] 組込みモデルを使用しないとき $(\mathrm{MODEL}=0)$, 大気の層の境界の位置や分子密度を与兄 3.

[CARD 3.1] IHAZE $\neq 0$ のとき, LOWTRAN5, LOWTRAN 6 飞組込まれたものと同じェアロゾル， 雲, 霧, 雨のモデルや減衰係数の指定を行う.

[CARD 3.2-3.6] 巻雲の高度の指定や user 指定のエ アロゾルデータを供給する.

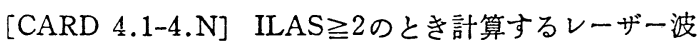

長 (波数 : $\mathrm{cm}^{-1}$ ) を指定する.

[CARD 5.1] 装置関数と convolution を取る

(ISCAN =1) とき, 半值幅, 関数形, convolution をと る対象（吸収, 透過, 放射輝度) を指定する.

[CARD 6.1] ISCAN=2 のとき, 計算結果をさらに補 間して細かい刻みでの結果を得る。

[CARD 7.1-7.N] IFILTR = 1 のとき, CARD 7.27.Nで与えられるフィルター関数を用いてフィルター透 過量を計算する.

[CARD 8.-8.3] IPLT=1のときプロッターに出力する ためのパラメーターを指定する. プロッターのコマンド は計算機によって若異なるので修正する必要がある.

プロッターを使用して表示した例は 4 節の計算例を参 照されたい。

またプログラムが正しく動くかチェックするために試 験入力データ (Fig. 4 の SYSIN.DATA, FILE 5) と そのときの出力データ（計算途中でのプリンターへの出 力とXYプロッターへの出力）が用意されており, プロ グラムが正しいかを確認できるようになっている.

この様に入カファイル (Fig. 4 の FILE 3) を用意す ると後は必要な計算条件は SYSIN.DATA から設定で きるようになっている。計算された結果は FILE 10,11, 12 亿保存される.

\section{3 抾張的使用法}

FASCODEはプログラムをそのままで使用する以外飞 計算した光学的厚さをもとにさらに他の用途に使用する ことが可能である. その方法としては

1) subroutine XMERGE で FILE $10(11,12)$ を製 作した後，FILE 10 のデータを読みだして別のプログラ ムで計算する.

2) FASCOD2 の中で，FILE 10 を製作した後，別の subroutine を挿入して, 計算を行う.

拡張的な使用法の例としては FASCOD2 で $\mathrm{CH}_{4}$ の $3.39 \mu \mathrm{m}$ の吸収線を計算した後, 実際に近い条件で周波 数変調法のスペクトルを計算し, 感度の計算を行った 例 ${ }^{38)}$ が相当する.

\section{4. 計 算 例}

大気中で透過率を計算する場合, 水蒸気（湿度）の影 響が問題になることが多い39).とくに水蒸気の吸収のあ る近赤外領域の $930-960 \mathrm{~nm}\left(10,400-10,800 \mathrm{~cm}^{-1}\right)$ と 1.35-1.43 $\mu \mathrm{m}\left(7,000-7,450 \mathrm{~cm}^{-1}\right)$ について東京におけ る冬 (1月) と夏 (7月)の透過率の比較を Fig. 5 (930 $\mathrm{nm}$ 帯) と Fig. 6 (1.3 $\mu \mathrm{m}$ 帯) に示す.

前節で述べたように, FASCODE では一回の計算で 


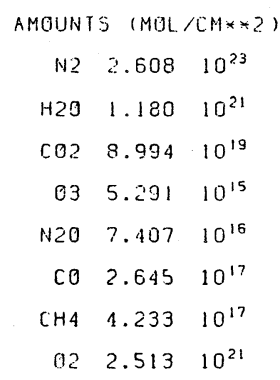

$$
\begin{aligned}
& \text { AMOUNTS } \\
& \begin{array}{rll}
\text { N2 } & 2.365 & 10^{23} \\
\text { H2O } & 5.996 & 10^{21} \\
\text { CO2 } & 8.327 & 10^{19} \\
03 & 4.899 & 10^{15} \\
\text { N2O } & 6.858 & 10^{16} \\
\text { CO } & 2.449 & 10^{17} \\
\text { CH4 } & 3.919 & 10^{17} \\
\text { O2 } & 2.327 & 10^{21}
\end{array}
\end{aligned}
$$
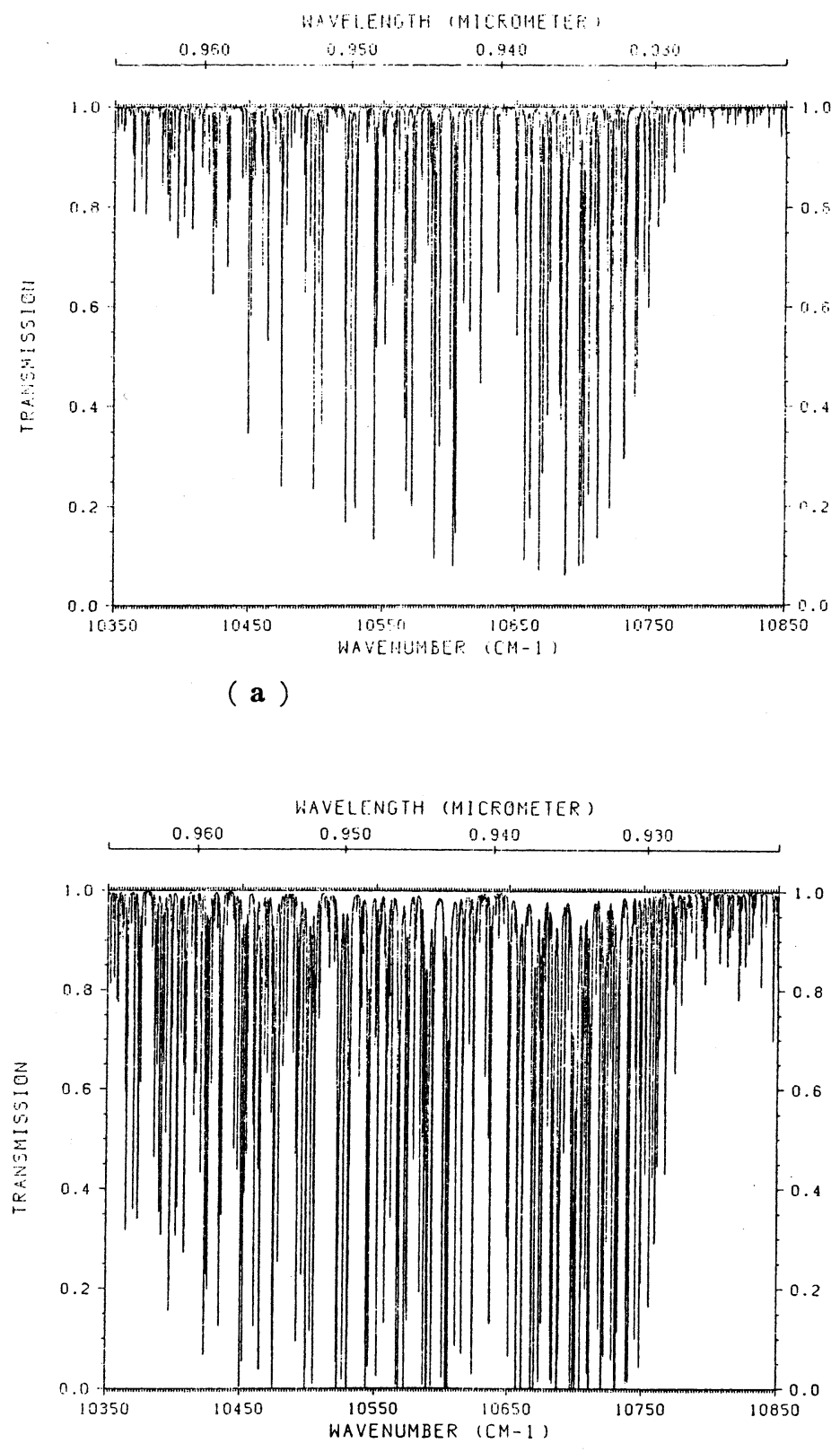

( b )

Fig. 5 Transmission through the $10 \mathrm{~m}$-path atmosphere in the (200)-(000) band region (930$960 \mathrm{um}$ ). (a) Typical transmission in winter (January) in Tokyo: temperature (T) $4.7^{\circ} \mathrm{C}$, relative humidity (R. H.) $53 \%$, pressure (p) $1014.8 \mathrm{mb}$. (b) Typical transmission in summer (July) in Tokyo: $\mathrm{T}=25.2^{\circ} \mathrm{C}, \mathrm{R} . \mathrm{H} .=77 \%, \mathrm{p}=1009.7 \mathrm{mb}$. 


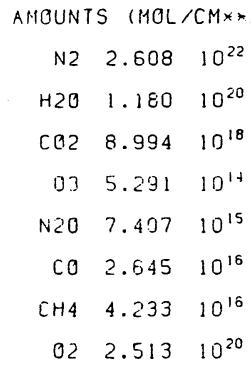

$$
\begin{array}{lll}
\text { AMOUNIS } & \text { (MOL } / \mathrm{CN} * \times 2) \\
\text { N2 } & 2.365 & 10^{22} \\
\mathrm{H} 20 & 5.956 & 10^{20} \\
\mathrm{CO} 2 & 8.327 & 10^{18} \\
\mathrm{O} 3 & 4.899 & 10^{14} \\
\mathrm{~N} 20 & 6.858 & 10^{15} \\
\mathrm{CO} & 2.449 & 10^{16} \\
\mathrm{CH} 4 & 3.919 & 10^{15} \\
\mathrm{O} 2 & 2.327 & 10^{20}
\end{array}
$$

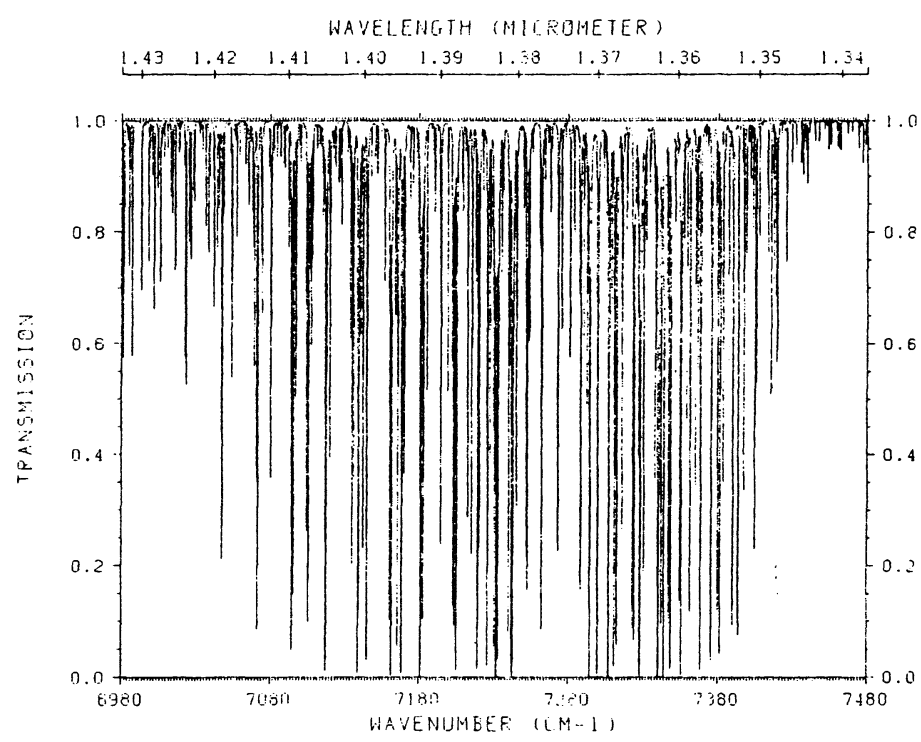

( a )

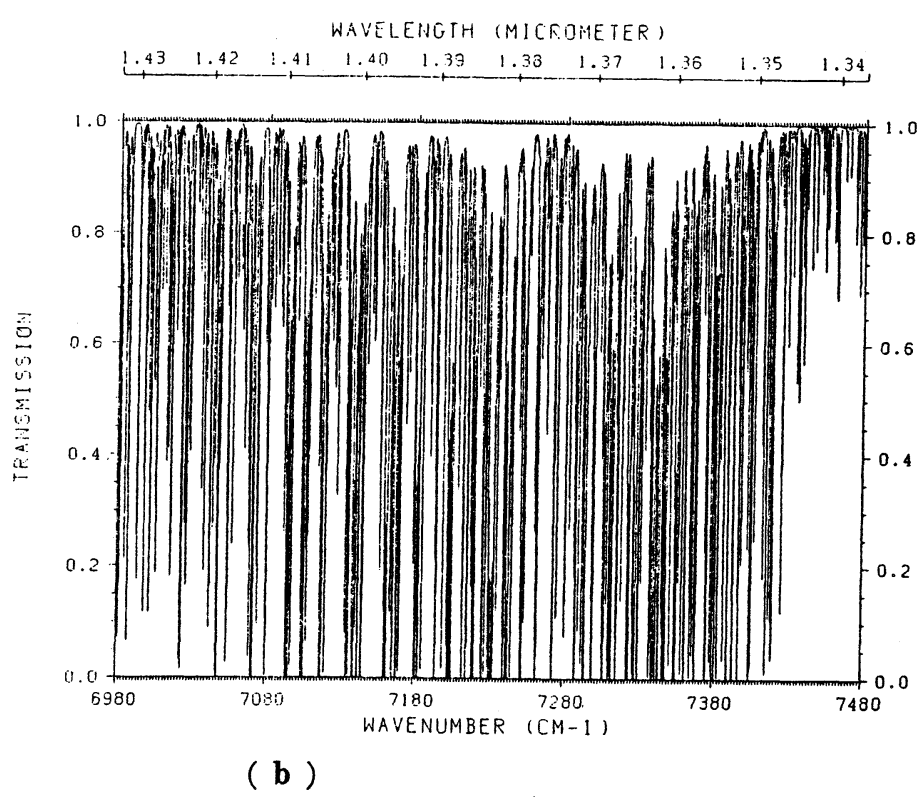

Fig. 6 Transmission through the $1 \mathrm{~m}$-path atmosphere in the (101)-(000) band region (1.35$1.43 \mu \mathrm{m})$. (a) Typical transmission in winter (January) in Tokyo: temperature (T) $4.7^{\circ} \mathrm{C}$, relative humidity (R. H.) $53 \%$, pressure (p) $1014.8 \mathrm{mb}$. (b) Typical transmission in summer (July) in Tokyo: $\mathrm{T}=25.2^{\circ} \mathrm{C}, \mathrm{R} . \mathrm{H} .=77 \%, \mathrm{p}=1009.7 \mathrm{mb}$. 
WAVELENGTH (MICROMETER)

\begin{tabular}{llllllllllllllllll}
20 & 10 & 16 & 14 & 12 & 10.0 & 9.0 & 8.0 & 9.0 & 6.6 & 6.3 & 6.0 & 5.7 & 5.4 & 5.1 \\
\hline
\end{tabular}

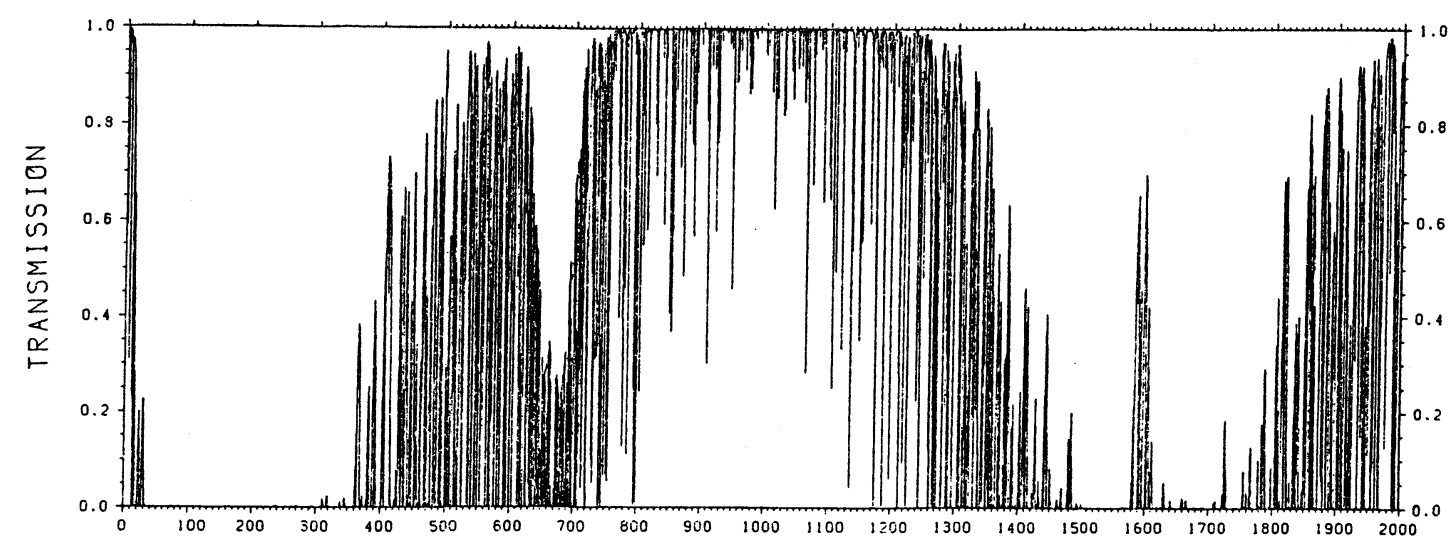

WAVENUMBER (CM-1)

Fig. 7 Atmospheric transmission at the ground level for the midlatitude-summer atmospheric model. The wavelength region is $5 \mu \mathrm{m} \sim \infty\left(0 \sim 2,000 \mathrm{~cm}^{-1}\right)$. The path length is $1 \mathrm{~m}$.

$525 \mathrm{~cm}^{-1}$ が限度である. そこで波数では短い区間とな る長波長領域を選び, $\lambda=5 \mu \mathrm{m} \sim \infty\left(0 \sim 2,000 \mathrm{~cm}^{-1}\right)$ の 区間を 4 つに分けて計算し，Fig. 7 に示す. 計算条件と しては FASCODE に組み込まれている大気光学モデル の内, 中緯度の夏モデル (midlatitude summer model : 地上での温度, 湿度, 圧力は $21^{\circ} \mathrm{C}, 75 \%\left(14 \mathrm{~g} / \mathrm{m}^{3}\right)$, $1,013 \mathrm{mb}$ である. また $\mathrm{N}_{2}, \mathrm{CO}_{2}, \mathrm{O}_{3}, \mathrm{~N}_{2} \mathrm{O}, \mathrm{CO}, \mathrm{CH}_{4}$,
$\mathrm{O}_{2}$ の濃度はそれぞれ $77.3 \%, 330 \mathrm{ppm}, 0.03 \mathrm{ppm}, 0.28$ ppm, $0.075 \mathrm{ppm}, 1.6 \mathrm{ppm}, 20.95 \%$ である）を選択し た. 光路長は $1 \mathrm{~m}$ である. Fig. 7 では 4 枚を 1 つの図 となるように貼合わせてある.

Figs. 5,6,7 には大気の主成分の地上に拈ける透過率 の計算例を示した．微量気体成分含めた計算例として大 気のモデルとして中緯度地方の夏モデルを取り, 地上

$$
\begin{array}{rll}
\text { AMOUNTS } & (\mathrm{MOL} / \mathrm{CM} \times 22) \\
\text { N2 } & 1.947 & 10^{23} \\
\text { H2O } & 6.488 & 10^{17} \\
\text { CO2 } & 6.488 & 10^{19} \\
03 & 3.932 & 10^{17} \\
\text { N2O } & 3.146 & 10^{16} \\
\text { CO } & 2.556 & 10^{15} \\
\text { CH4 } & 2.399 & 10^{17} \\
\text { O2 } & 1.789 & 10^{21} \\
\text { NO } & 0.000 & 10^{\circ} \\
\text { SO2 } & 0.000 & 10^{\circ} \\
\text { NO2 } & 0.000 & 10^{\circ} \\
\text { NH3 } & 0.000 & 10^{\circ} \\
\text { HNO3 } & 1.966 & 10^{17}
\end{array}
$$

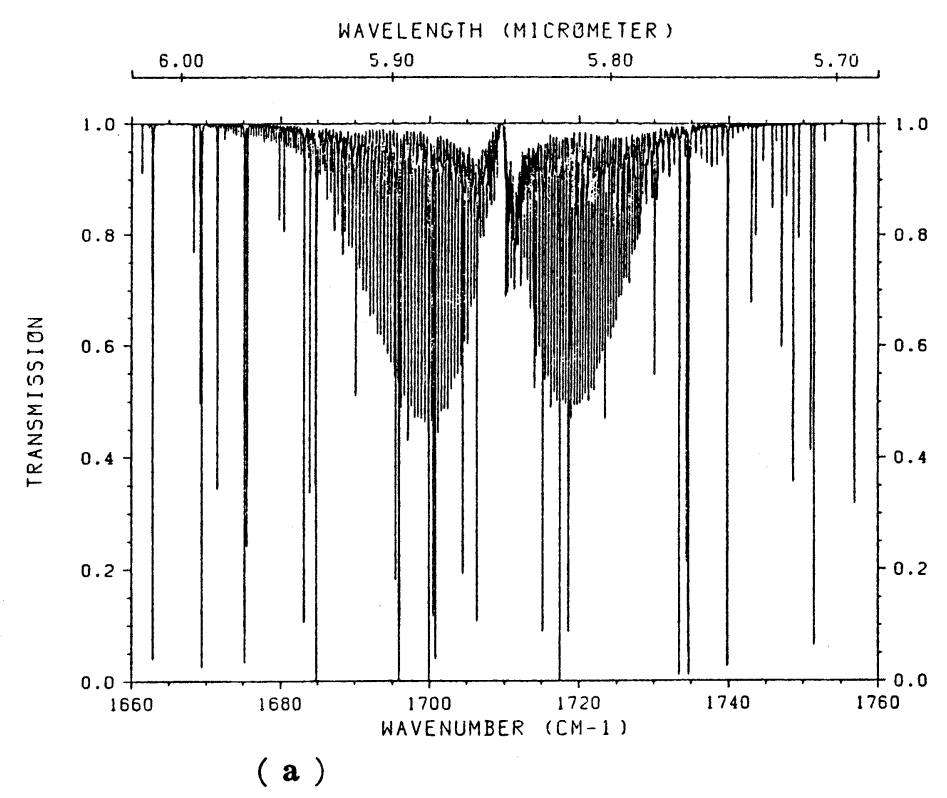


AMOUNTS (MOL $/$ CM**2)

$\begin{array}{rll}\text { N2 } & 1.948 & 10^{23} \\ \text { H2O } & 0.000 & 10^{\circ} \\ \text { CO2 } & 0.000 & 10^{\circ} \\ O 3 & 0.000 & 10^{\circ} \\ \text { N2O } & 0.000 & 10^{\circ} \\ \text { CO } & 0.000 & 10^{\circ} \\ \text { CH4 } & 3.932 & 10^{9} \\ \text { O2 } & 1.789 & 10^{21} \\ \text { NO } & 0.000 & 10^{\circ} \\ \text { SO2 } & 0.000 & 10^{\circ} \\ \text { NO2 } & 0.000 & 10^{\circ} \\ \text { NH3 } & 0.000 & 10^{\circ} \\ \text { HNO3 } & 1.966 & 10^{17}\end{array}$

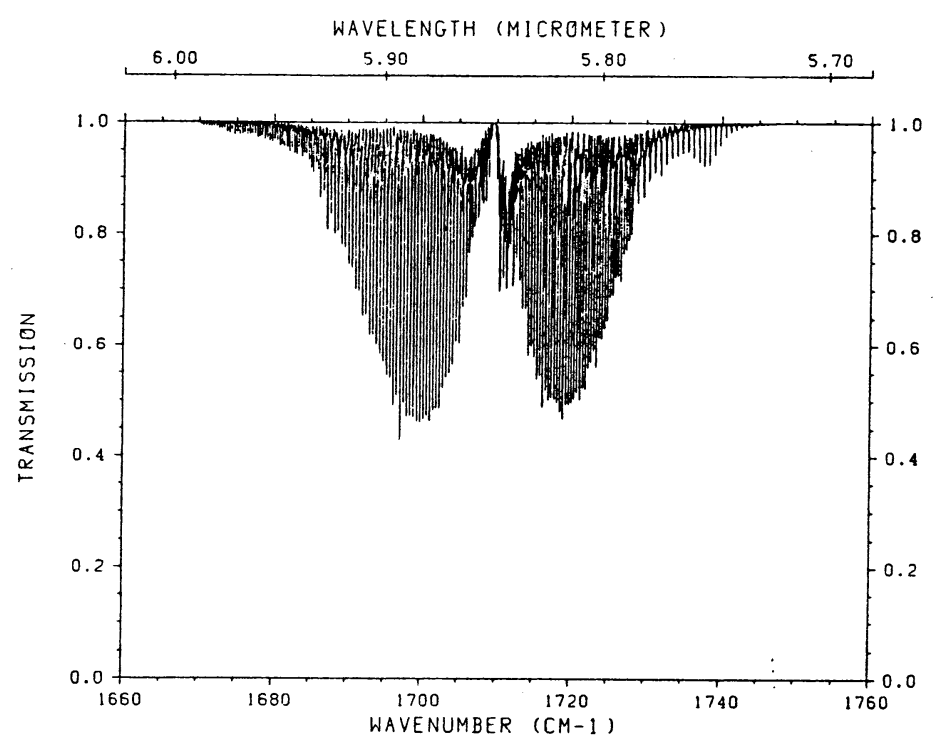

( b )

AMOUNTS (MOL/CM**2)

$\begin{array}{rll}\text { N2 } & 1.947 & 10^{23} \\ \text { H2O } & 6.488 & 10^{17} \\ \text { CO2 } & 6.488 & 10^{19} \\ \text { O3 } & 3.932 & 10^{17} \\ \text { N2O } & 3.146 & 10^{16} \\ \text { CO } & 2.556 & 10^{15} \\ \text { CH4 } & 2.399 & 10^{17} \\ \text { O2 } & 1.789 & 10^{21} \\ \text { NO } & 0.000 & 10^{0} \\ \text { SO2 } & 0.000 & 10^{\circ} \\ \text { NO2 } & 0.000 & 10^{\circ} \\ \text { NH3 } & 0.000 & 10^{\circ} \\ \text { HNO3 } & 1.966 & 10^{17}\end{array}$

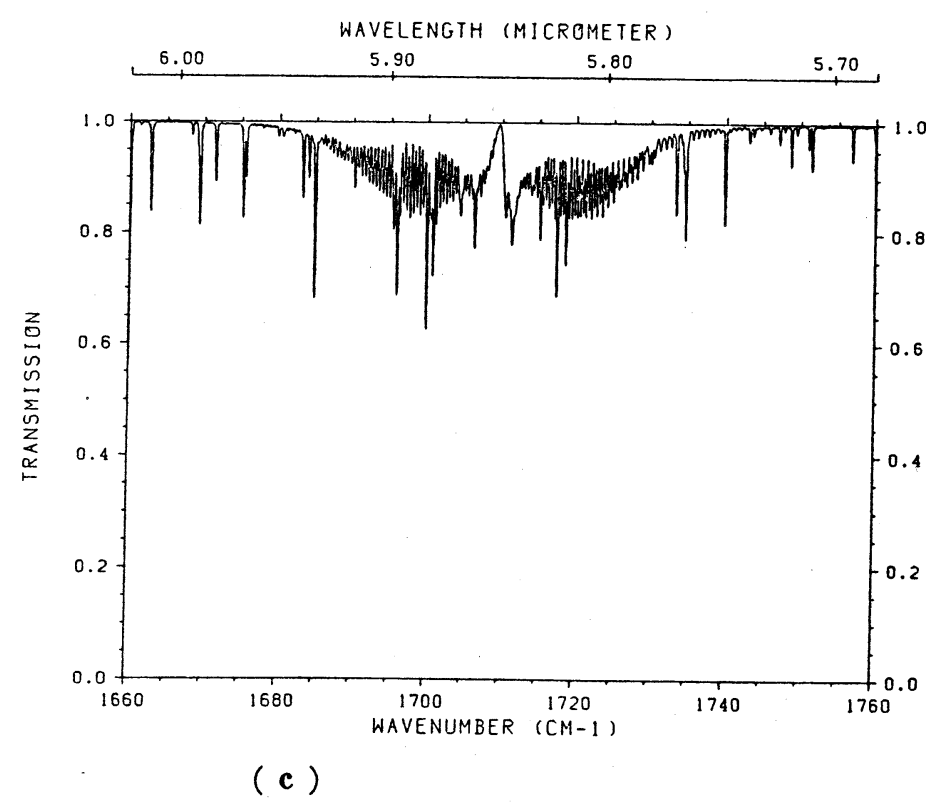

Fig. 8 Calculation of the trace gas in the atmosphere. Here a case where nitric acid is located at $20 \mathrm{~km}$ altitude with the concentration of $1 \mathrm{ppm}$ (roughly 200 times thicker than the typical value). (a) nitric acid with air. The path is $1 \mathrm{~km}$. The midlatitude summer model is used. (b) Pure $\mathrm{HNO}_{3}$ in no absorption air. The other condition is the same as the case (a). (c) The profile of (a) is scanned by slit function with the half width of $0.1 \mathrm{~cm}^{-1}$. 
$20 \mathrm{~km} \mathrm{~V} \mathrm{HNO}_{3}$ か $1 \mathrm{ppm}$ 存在した場合の光路 $1 \mathrm{~km}$ に対する $5.7 \sim 6.0 \mu \mathrm{m}\left(1,660-1,760 \mathrm{~cm}^{-1}\right)$ の領域の透 過率を Fig. 8(a) に示す. このときの $\mathrm{HNO}_{3}$ と非吸収 気体以外の気体が存在しない場合の透過率の計算をFig. 8(b) に示した. また分解能が半値半幅 $0.1 \mathrm{~cm}^{-1}$ である 分光器のスリットを通して受光したときのスペクトル波 形を Fig. 8(c) に示す.

このように条件を設定して容易に大気中の透過率や光 学的厚さを計算でき, 局所平衡定理を仮定して放射輝度 を求めることができる.

FASCOD2 では一回で計算できる波長範囲は $500 \mathrm{~cm}^{-1}$ である. その計算時間は，含まれる遷移の本数にも依る が，1気圧では HITAC M280を用いた場合，CPU 時 間で約20〜40秒である.

\section{5. 結 び}

以上 FASCODE について分光計測への応用の観点か ら単一の層について, 主として吸収, 光学的厚さといっ た観点から述べた。FASCODEは成層圈に至る環境大気 で使用することを主の目的として製作されており，それ らに関連した事情についてここで補足する.

\section{1 層別計算}

CARD 2-2 2-4 で設定された光路が異なる高度を持 つとき一定の幅を持つ高度毎の大気の層に分けてその層 に含まれる分子数 (column density) を計算する. 層の 数は, 最大 67 層まで設定することが可能であるが, FASCODE の内部に組み込まれている分け方では LOWTRAN6 (1.1 節参照) と同じく地上から $120 \mathrm{~km}$ までを33層に分けている. スペクトル幅は粗いところか ら計算し次第に細分かする方が計算が容易であるので, 王力（気圧）は高い方から低い方へ計算する，そのため に高度が高い点から地球へ一度接近して再び離れるとき でもそれぞれの層にある分子数を予め積算し，下層から 計算する方法を採用している. 隣合ら層の間のスペクト ル幅の比は 2 倍を越えないように配慮されて括り, 圧力 比によって, 分割の幅は $4: 5,3: 4,2: 3,1: 2$ と整数比 になるように選ばれて扣り，計算する点(波数值)の変更 ががなるべく少なくなるように配慮されている.

最近地球大気の観測に使用されるようになった分光也 ンサー40)にはサウンダーと limb scanner がある.サ ウンダーは地上方向の大気からの放射を複数個の波長帯 で測定し，途中での吸収によってそれぞれの層からの放 射に寄与する量（これを weighting function という） が異なることを利用してその層にある分子密度または温 度を求める測定器である. また limb scanner では衛星
から地球をかすめるようにして方向を変えながら太陽光 の透過光を測定し，その違いから分子密度を求める. サ ウンダーでも limb scanner でも反転問題を解く方法に よって分子密度を求める. この weighting function の 計算や方向別の透過量の推定に FASCODE は大きな効 果を発揮する.

\section{5,2 放射輝度}

ここで大気の光学的厚さから放射輝度を求める手順を 簡単に紹介する.

放射に関する用語は色々異なった定義が用いられてい るが，ここでは単位時間に単位面積を通過する電磁波の エネルギー（放射束密度）を放射輝度と呼ぶ41). FASCODEでは放射輝度の計算を上空から地上方向を眺 める ( $E_{\text {down }}$ : 計算されるのは上向きの flux) ときと, 地上から上空を眺めるとき $\left(E_{\mathrm{up}}\right.$ : 計算されるのは下向き の flux) との二つに分けている (Fig. 9). いずれの場合 も大気の層を $n$ 層に分けて (下から $1,2,3, \cdots, n$ と数え る), それぞれの層 $i$ のでは吸収されたエネルギー $(1-$ $T_{i}$ ) が局所平衡定理によってその層の温度 $\theta$ で決まる黒 体放射 $(p(\theta, \nu))$ によって再放出されるものと仮定する. $E_{\text {down }}$ の計算では地表面 (温度 $\theta_{g}$ ) の放射, $E_{\text {up }}$ の計算 では最上層 (温度 $\theta_{n}$ ) の放射は大気の減衰を受けて観測 地点へ達する. 途中の層を源とする放射はその後の光路 での減衰を受ける40)41). FASCODEでは光学的厚さの計 算で下層（圧力の高い方）から計算して行くので, 放射 輝度も下層から上層へ計算を積み上げていく。このと き, $i$ 層での放射輝度は

$$
E \mathrm{up}(i)=E \mathrm{up}(i-1)+\left(1-\Delta T_{i}\right) P(i) T(i-1)
$$

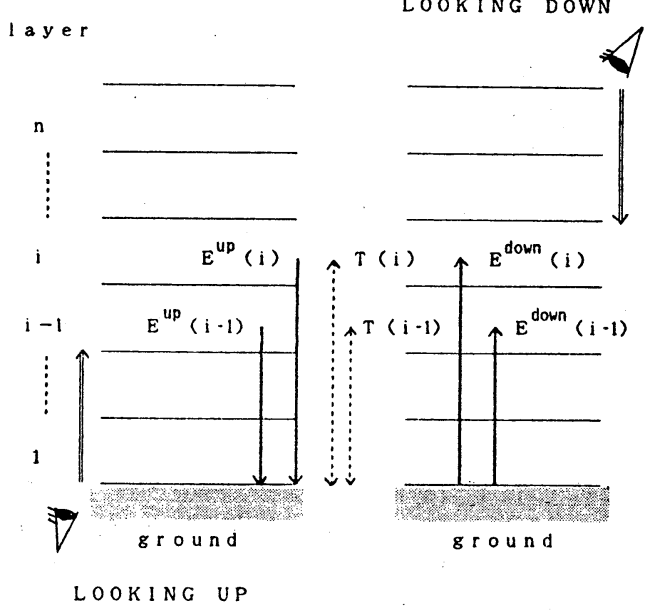

Fig. 9 Scheme of calculation of radiance for up-looking cases. $T(i)=T(i-1) \cdot \Delta T_{i}$. 


$$
E^{\text {down }(i)}=\Delta T_{i} E_{\text {down }}(i-1)+\left(1-\Delta T_{i}\right) P(i)
$$

で与えられる.ここで $E$ up,$E$ down は上向きおよび下向 き観測するときの放射輝度である. $\Delta T_{i}$ は $i$ 層での透 過率で, $T_{i}=T_{i-1} \cdot \Delta T_{i}$ の関係がある. $P(i)$ は $i$ 層の温 度で決まるプランクの放射の式で

$$
P(i)=\frac{2 h c^{2} \nu^{3}}{\exp (h c \nu / k \theta)-1}
$$

である.（12）式の計算では $h c \nu / k \theta><80$ によって2つ の領域を分け，ほほ $P(\nu)$ の平均值を黒体放射の計算に 用いている. FASCODE の放射輝度計算では $n$ 層（組 み込まれたモデルによって自動的に決めることも user がデータを与えることも可能である）に分けたそれぞれ の層の光学的厚さと温度で与えられる下向き $(E \mathrm{up})$ ， たは上向き $(E$ down $)$ の放射輝度あるいは式(13)を用いて 換算した観測地点での輝度温度を波長の関数として計算 することができる. 以上は局所的な熱平衡状態が成立し ているときの計算であるが，層別の非平衡温度あるいは 非平衡温度が分子種別に与えられているときには, 非平 衡状態の計算も可能である. またプログラムを多少いじ ることによって大気が加熱されるか，あるいは冷却され るかの地球の熱収支の計算にも応用することが可能であ る.

\section{3 今後の問題点}

第2版（FASCOD2）となって非常に便利となった FASCODEプログラムであるが，さらに残っている課題 には，1）OLP の高精度化，2）超 Lorentzian (line profile)の記載，がまず挙げられる.これらは新しい'86 年版の OLP ${ }^{36)}$ にはかなり改良されたデータが収録され ているが，その特長を生かすためにはさらにFASCODE を改訂することが必要となるう，次に放射輝度導出に関 してであるが，3）多重散乱 (multiple scattering) の組 込み，4）太陽放射（solar radiation：LOWTRAN6 で は既に取り込まれている）の組込み，が望まれる，さら に最終的には取り組まなければならない問題に，5）光 路の摇らぎ (turbulence) がある.これは現在の FASCODE プログラムでは同じ層の中では気圧も温度も一定 で分子密度に摇らぎがなく光はいつも同じ光路を通過す ることなっているが，実際には地表付近ではゆらぎのた めに光路が歪むことが起こり得る.この様な効果を取り 入れることも最終的には必要となるであるう.

以上 FASCODE を分光計測に使用するときに必要な 情報の紹介という観点から紹介した，FASCODEの本来 の目的である大気の透過・放射輝度の予測という観点の 紹介はまた別の機会に譲りたい。
最後に本解説で紹介した FASCODE プログラムは CDC (Control Data Corporation) 社の64ビット計算機 用の言語で書かれて拈り，IBM compatible の FORTRAN に修正するに当たっては国立公害研究所計算機 室の古川満信氏，塚田良一氏，猪爪京子氏の多大な協力 があったことを記し感謝する，またブロ.グラムの修正・ 改良には大島徹也氏（慶応大学理工学部）の協力があっ たことを記し，感謝する。

\section{参考文 献}

1) H.J.P. Smith, D. J. Dube, M.E. Gardner, S.A. Clough, F.X. Kneizys and L.S. Rothman: FASCODE-Fast Atmospheric Signature Code (Spectral Transmittance and Radiance) AFGLTR-78-0081 (1978).

2) S.A. Clough, F.X. Kneizys, L.S. Rothman and W.O. Gallery: Atmospheric Spectral Transmittance and Radiance: FASCOD1B, Proc. of SPIE, 277, Atm. Transm. (1981).

3) S.A. Clough, F.X. Kneizys, E.P. Shettle and G.P. Anderson: Atmospheric Radiance and Transmittance: FASCOD2, Proc. 6th Conf. Atmos. Rad. (May 1986).

4) F.X. Kneizys, E.P. Shettle, W.O. Gallery, J.H. Chetwynd, Jr., L.W. Abreu, J.E. A. Selby, R.W. Fenn and R.A. McClatchey: Atmospheric Transmittance/Radiance: Computer Code LOWTRAN 5, AFGL-TR-80-0067. 233pp. (1980).

5) F.X. Kneizys, E.P. Shettle, W. O. Gallery, J.H. Chetwynd, Lr., L.W. Abreu, J.E. A. Selby, S. A. Clough and R.W. Fenn: Atmospheric Transmittance/Radiance: Computer Code LOWTRAN 6, AFGL-TR-83-0187. 200pp. (1983).

6) T.L. Altshuler: Infrared Transmission and Background Radiation by Clear Atmosphere, GE Report 61 SD 199, AD-401923.

7) R.A. McClatchey, R.W. Fenn, J.E.A. Selby, F.E. Volt and J.S. Garing: Optical Properties of the Atmosphere (third edition), AFCRL Report AFCRL-72-0497. (1972).

8) R.G. Isaacs, W.-C. Wang, W.D. Worsham and S. Goldenberg: Appl. Opt. 26, 1272 (1987).

9) 川田剛之, 川端一弘, 日下 迢, 上野季夫：日本り モートセンシング学会誌, 3, 21 (1983).

10) E. Niple: Appl. Opt. 20, 3481 (1980).

11) D.T. Cassidy and J. Reid: Appl. Opt. 21, 2527 (1982).

12) V.M. Devi, C.P. Rinsland, M. A. H. Smith and D. C. Benner: Appl. Opt. 24, 2788 (1985).

13) E. Trakhovsky: Appl. Opt. 24, 3519 (1985).

14) C.P. Rinsland, M. A. H. Smith, J. M. Russel III, J.H. Park and C.B. Farmer: Appl. Opt. 20, 4167 (1981). 
15) C.P. Rinsland, M. A.H. Smith, R. K. Seals, Jr., A. Goldman, F. J. Murcray, D. G. Murcray, J. C. Larsen and P.L. Rarig: J. Geo. Res. 87, 3119 (1982).

16) M.T. Coffey, W.G. Mankin and R. J. Cicerone: Science 214, 333 (1981).

17) J.R. Drummond and C.T. Mutlow: Nature 294, 431 (1981).

18) D. H. Leslie and G. L. Trusty: Appl. Opt. 20, 1941 (1981).

19) T.A. Wiggins: Appl. Opt. 20, 3481 (1981).

20) N. Menyuk and D. Killinger: Appl. Opt. 26, 3061 (1987).

21) W. B. Grant, J.S. Margolis, A. M. Brothers and D. M. Tratt: Appl. Opt. 26, 3033 (1987).

22) J. M. Hoell, C. N. Harvard and B.S. Williams : Geo. Res. Letters 7, 313 (1980).

23) J.H. Pierluissi and K. Tomiyama: Appl. Opt. 19, 2298 (1980).

24) D.C. Robertson, L.S. Bernstein, R. Haimes, J. Wunderlich and L. Vega: Appl. Opt. 20, 3218 (1981).

25) W.M. Wehrbein and C.B. Leovy: J. Atmos. Science 39, 1532 (1982).

26) J.T. Kiehl and R.E. Dickinson: J. Geo. Res. 92, 2991 (1987).

27) K. L. Lehmann, G. J. Sherer and W. Klemperer : J. Chem. Phys. 77, 2953 (1982).

28) S. A. Clough, F.X. Kneyzys and J.H. Chetwind, Jr.: Algorithm for the Calculation of Absorption Coefficient-Pressure Broadened Molecular Transitions, AFGL-TR-77-0164, (1977).

29) E.E. Whiting: J. Quant. Spectr. Rad. Trans. 16, 611 (1976).
30) J.F. Kielkopf : J. Opt. Soc. Am. 63, 987 (1973).

31) J.H. Van Vleck and D.L. Huber: Rev. Mod. Phys. 49/4, 939 (1977).

32) R. A. McClatchey, W.S. Benedict, S. A. Clough, D. E. Burch, R. F. Calfee, K. Fox, L.S. Rothman and J.S. Garing: AFGL Atmospheric Line Parameters Compilation, AFCRL-TR-73-0096. (1973).

33) L.S. Rothman, R.R. Ganache, A. Barbe, A Goldman, J.R. Gillis, L.R. Brown, R. A. Toth, J. M. Flaud and C. Cany-Peyret: Appl. Opt. 22, 2247 (1983).

34) L. S. Rothman, A. Goldman, J.R. Gillis, R. R. Ganache, H. M. Pickett, R. L. Pointer, M. Husson and A. Chedin: Appl. Opt. 22, 1616 (1983).

35) W.L. Rigway, R.A. Moose and A.C. Cogley: Atmospheric Transmittance/Radiance Computer Code FASCOD2, AFGL-TR-82-0392.

36) L.S. Rothman: Appl. Opt. Oct. 1 (1987) 号印刷 中.

37) A. Chedin, N. Husson, N. A. Scott, I. CohenHallaleh and A. Berroir: "GEISHA" data bank 1984 version. Laboratorie de Meteorologie Dynamique.

38）竹内延夫, 大島徹也：分光研究，36，265 (1987).

39）竹内延夫：半導体レーザーを光源とする大気湿度の 測定について一AFGL 大気光学モデルによる検討. 第 4 回光波利用センシング 研究会予稿, 49-52. (1986. 12. 3).

40) 竹内延夫：日本りモートセンシング 学会誌 6,99 (1986).

41) 会田 勝: 大気と放射過程, 気象学のプロムナード 8 , 東京堂出版, $280 \mathrm{pp}, 1982$.

\section{【校正時の追加】}

米国 Massachusetts 州 Cape Cod で開かれた Laser \& Optical Remote sensing の topical meeting (1987 9/28-10/1) の後, Boston 郊外にある Air Force Geophysics Lab. (AFGL) に FASCODE を製作したグループ を訪ねた. R.W. Fenn, S. A. Clough は退官し, 現在の坦当は HITRAN data base $か$ L.S. Rothman, LOWTRAN $\not$; F. X. Kneizys, FASCODE が G.P. Anderson, エアロゾルモデルが E.P. Shettle である. OLP の 1986年版では $\mathrm{CO}_{2}, \mathrm{H}_{2} \mathrm{O}$ のデータが大いに改良されている. データの比較・ 校正には AFGL に拈けるスキャン長 $2 \mathrm{~m}$ の FTIR を用いているばかりで なく，GEISHA チーム（仏）を含めた世界各国のグループとも連絡をとって データの改良に努めている. 日本の研究グループとも連絡を取りたいとのこ とであった．多重散乱についてはすでに FASCODE, LOWTRAN に組み込 むためにプログラムが完成している (R.G. Isaacs et al：Mulitiple scattering treatment for use in the LOWTRAN and FASCODE models, AFGL-TR-86-0073)。これらを盛り込み，新項目を含んだ86年版 OLP のデ 一タを有効に使用できる FASCOD3が間もなく完成するとのことであった。 大気の摇らぎ (turbulence) そついてはすでに別のプログラムが完成してい るが FASCODE，LOWTRAN と組み合わせる予定は無いとのことであっ た. 